\title{
In vitro acquired cellular senescence and aging-specific phenotype can be distinguished on the basis of specific mRNA expression
}

\author{
doi:10.1038/sj.cdd.4401053
}

\section{Dear Editor,}

The contribution of cellular senescence to the aging of animals is still a controversial issue. Human diploid fibroblasts can be cultured in vitro for a finite number of divisions, after which they undergo a metabolic condition called replicative senescence. $^{1,2}$ This condition is characterized by the absence of response to mitogenic stimuli and elevated levels of cyclin-dependent kinase inhibitors, ${ }^{3}$ which in turn could be responsible for the presence in these cells of dephosphorylated retinoblastoma protein and low E2F transcription factor activity. $^{4,5}$ Furthermore, there is convincing experimental evidence that telomere shortening plays a key role in the establishment of the senescent phenotype. ${ }^{6,7}$ Cells derived from old individuals share with in vitro senescent cells some cellular and molecular phenotypes, but it is not clear whether these phenotypes are completely overlapping. The data currently available show that normal cells from aged donors have a proliferative potential lower than those taken from young individuals ${ }^{8-12}$ and, consistently, cells from patients suffering from diseases characterized by a precocious senescence, such as Werner's syndrome, Down's syndrome and Hutchinson-Gilford progeria, show a significant impairment of proliferative potential compared to cells from healthy donors of comparable ages. ${ }^{13-17}$ Other results, however, showed that, in a large series of normal subjects of various ages, the maximal population doubling of skin fibroblasts is completely independent from the age of the donor. ${ }^{18}$ Furthermore, in vivo aged cells, like in vitro senescent fibroblasts, show the appearance of the senescenceassociated $\beta$-galactosidase activity, ${ }^{19}$ and the accumulation of cyclin-dependent kinase inhibitors, p2 $1^{\text {waf1 }}$ and $\mathrm{p} 16 .^{3,20,21}$

A direct approach to address the possible relationship between cells undergoing in vitro replicative senescence and cells taken from old subjects is to compare their gene expression profiles.

In a recent paper, the expression profile of human fibroblasts taken from old subjects has been compared to that of cells taken from young individuals, ${ }^{22}$ showing that there are numerous genes expressed at different levels in these two types of cells. We selected some of these genes to analyze whether the differences of their expression observed in fibroblasts taken from old vs young individuals could be similarly observed with the appearance of in vitro acquired replicative senescence.

The cells used for this study were: (i) IMR-90 human embryo fibroblasts (EF); (ii) two populations of skin fibroblasts taken from young donors of 7 and 9 years (CRL-1474 and CRL-7469), indicated as YF1 and YF2, respectively; (iii) two populations of skin fibroblasts taken antemortem from old individuals of 92 and 96 years of age (AG04064A and AG04059B) indicated as OF1 and OF2, respectively. Proliferation capacity of these cells was examined at different Population Doubling Level (PDL) by measuring BrdU incorporation, during 48 hour incubation in the presence of the nucleoside. EF cell BrdU incorporation is $>90 \%$ until $50 \mathrm{PDL}$, and thereafter decreases, reaching a mean value of $5 \%$ at 60 PDL $\left(E_{60}\right)$. YF1 and YF2 cells have a percentage of BrdU incorporation very similar to that of EF cells at 25 PDL $\left(E_{25}\right)$, which remains elevated until 35 PDL. OF1 and OF2 cells maintained in culture up to 20 PDL showed more than $85 \%$ of BrdU positive cells, but this percentage decreases after a few more PDL (only $6 \%$ of BrdU positive cells after 25 PDL).

We also measured the levels of $\mathrm{p} 21^{\text {waf1 }} \mathrm{mRNA}$ and the number of SA $\beta$-gal positive cells; p $21^{\text {waf1 }}$ mRNA is low in $\mathrm{EF}_{28}, \mathrm{YF} 1$ and $\mathrm{YF} 2$ cells, in which SA $\beta$-gal positive cells are quite absent, while $\mathrm{EF}_{60}$ and $\mathrm{OF}$ cells contain several fold more p21 mRNA than $\mathrm{EF}_{28}$ and $\mathrm{YF}$ cells and a high percentage of SA $\beta$-gal positive cells $(\geqslant 50 \%)$. In conclusion these results are in agreement with the observations reported by others, indicating that cells taken from old individuals are similar to the cells that acquired the senescent phenotype in vitro: in fact, they have a limited proliferation potential, show increased levels of $\mathrm{p} 21^{\text {waf1 }}$ mRNA and most of them are SA $\beta$-gal positive.

To further examine this similarity we analyzed by quantitative real-time PCR the levels of expression of some genes in the various cell populations under examination. Table 1 shows that the two mRNAs encoding prostaglandin endoperoxide synthase (PTGS1) and fibromodulin (Fmod) are significantly increased in OF1 and OF2 cells compared to $\mathrm{YF1}$, in agreement to that reported in the paper of Ly et al. $^{22}$ The mRNA levels of these genes in YF2 cells are very similar to those present in YF1 cells (data not shown). In particular, we found that $\mathrm{OF} 1_{20}$ cells compared to YF1 cells, on three different RNA preparations each measured in triplicate, have 16-fold more PTGS1 mRNA and 20-fold more Fmod mRNA. These differences were confirmed when we analyzed the RNA from OF $1_{25}$ cells (slowly- or not-dividing cells, see above), although the differences were less strong. On the contrary, the concentration of PTGS1 mRNA in senescent $\mathrm{EF}_{60}$ cells is similar to that observed in $\mathrm{EF}_{28}$ cells, while Fmod mRNA shows an opposite change, being decreased by more than sevenfold in $\mathrm{EF}_{60}$ compared to $\mathrm{EF}_{28}$ cells. 
Table 1 Gene expression levels in in vitro senescent cells and in cells from old individuals

\begin{tabular}{|c|c|c|c|c|c|c|c|c|}
\hline \multirow[b]{2}{*}{$\begin{array}{l}\text { GENE } \\
\text { (Acc. N.) }\end{array}$} & \multirow[b]{2}{*}{$\begin{array}{c}\mathrm{OF}_{20} \text { vs } \\
\text { YF1 }\end{array}$} & \multirow[b]{2}{*}{$\begin{array}{l}\text { OF2 vs } \\
\text { YF1 }\end{array}$} & \multirow[b]{2}{*}{$\begin{array}{c}\mathrm{OF}_{25} \text { vs } \\
\text { YF1 }\end{array}$} & \multirow[b]{2}{*}{$\begin{array}{c}\mathrm{EF}_{60} \text { vs } \\
\mathrm{EF}_{28}\end{array}$} & \multicolumn{3}{|c|}{$\mathrm{EF}_{28}$} & \multirow[b]{2}{*}{ Oligonucleotides } \\
\hline & & & & & $\begin{array}{c}\text { DEM } \\
2 \text { days }\end{array}$ & $\begin{array}{c}\text { DEM } \\
4 \text { days }\end{array}$ & $\begin{array}{c}\text { DEM } \\
6 \text { days }\end{array}$ & \\
\hline $\begin{array}{l}\text { PTGS1 } \\
\text { (M59979) }\end{array}$ & 16.1 & 12.4 & 8.0 & 1.3 & 1.1 & -1.5 & -6.3 & $\begin{array}{l}\text { F.P.: CCAGGAGTACAGCTACGAGCAGT } \\
\text { R.P.: AGGATGTGGTGGTCCATGTTC } \\
\text { Probe: CTGGTGGATGCCTTCTCTCGCCA }\end{array}$ \\
\hline $\begin{array}{l}\text { Fmod } \\
\text { (U05291) }\end{array}$ & 20.8 & 19.3 & 16.6 & -7.3 & 1.3 & -2.2 & -3.8 & $\begin{array}{l}\text { F.P.: CTACCTCCAAGGCAATAGGATCA } \\
\text { R.P.: TGGCGCTGCGCTTGA } \\
\text { Probe: TGCGCCTGGACGGGAACGA }\end{array}$ \\
\hline $\begin{array}{l}\text { CatC } \\
\text { (X87212) }\end{array}$ & 2.1 & 1.6 & -1.1 & 1.2 & -1.5 & -1.4 & -2.0 & $\begin{array}{l}\text { F.P.: CCCCAATCCTAAGCCCTCAG } \\
\text { R.P.: GGCGTACTTTCCTGCAATAAGG } \\
\text { Probe: TTGTGTCTTGTAGCCAGTATGCTCAAGGCTGT }\end{array}$ \\
\hline $\begin{array}{l}\text { HME } \\
\text { (L23808) }\end{array}$ & 5.0 & 2.8 & 2.5 & 2.2 & 2.6 & 12.5 & 8.2 & $\begin{array}{l}\text { F.P.: ACCCACGTTTTTATAGGACCTACTTC } \\
\text { R.P.: GAAGTTCTTGGTAATCAGTTTGGGA } \\
\text { Probe: TATTGGAGGTATGATGAAAGGAGACAGAT- } \\
\text { GATGGA }\end{array}$ \\
\hline $\begin{array}{l}\text { CycA } \\
\text { (X51688) }\end{array}$ & -1.1 & 1.2 & -4.8 & -11.5 & -11.1 & -9.1 & -17.0 & $\begin{array}{l}\text { F.P.: TGGGCACTGCTGCTATGCT } \\
\text { R.P.: TTTCTTGGTGTAGGTATCATCTGTAATGT } \\
\text { Probe: AAGAAATATACCCCCCAGAAGTAGCA- } \\
\text { GAGTTTGTG }\end{array}$ \\
\hline $\begin{array}{l}\text { CycF } \\
\text { (Z36714) }\end{array}$ & -1.1 & -1.4 & -4.9 & -5.4 & -4.0 & -5.6 & -6.3 & $\begin{array}{l}\text { F.P.: GTGGTCGGTGAGCGGAAG } \\
\text { R.P.: TGCAATATGGATGCTTTGTGAGT } \\
\text { Probe: CTGCAAGGCCGTGGTTCACGAGA }\end{array}$ \\
\hline $\begin{array}{l}\text { TS } \\
\text { (D00596) }\end{array}$ & -1.3 & 1.5 & -3.6 & -4.7 & -1.8 & -3.5 & -14.0 & $\begin{array}{l}\text { F.P.: GAGGAGTTGCTGTGGTTTATCAAG } \\
\text { R.P.: CCCAGGCTGTCCAAAAAGTC } \\
\text { Probe: AAGGGAGTGAAAATCTGGGATGCCAATG }\end{array}$ \\
\hline $\begin{array}{l}\text { HFH-11A } \\
\text { (U74612) }\end{array}$ & 1.1 & 1.4 & -4.3 & -6.4 & -3.7 & -12.5 & -21.2 & $\begin{array}{l}\text { F.P.: AGCCCTTTGCGAGCAGAA } \\
\text { R.P.: CCACTGGATGTTGGATAGGCTAT } \\
\text { Probe: TGCAGATGGTGAGGCAGCAGGCT }\end{array}$ \\
\hline $\begin{array}{l}\text { Ucar } \\
\text { (U73379) }\end{array}$ & 1.0 & -1.6 & -5.7 & -8.4 & -6.6 & -12.2 & -15.0 & $\begin{array}{l}\text { F.P.: GGGATTTCTGCCTTCCTGA } \\
\text { R.P.: GCATTGTAAGGGTAGCCACTGG } \\
\text { Probe: TCAGACAACCTTTTCAAATGGGTAGGGACC }\end{array}$ \\
\hline
\end{tabular}

EF cells (for the cell name abbreviations see text), purchased from ATCC at PDL 24, were subcultured weekly in Dulbecco's modified Eagle's medium (DMEM, Gibco/ $\mathrm{BRL}$ ), containing $10 \%$ foetal bovine serum (Gibco/BRL, New Zealand) in $5 \% \mathrm{CO}_{2}$ at $37^{\circ} \mathrm{C}$. The population doubling level (PDL) at each subcultivation was calculated from the cell counts by using the equation: $X=\log _{2} N_{H} / N_{1}$, where $N_{1}=$ starting number, $N_{H}=$ number of harvested cells. OF1 cells were grown in Minimum Essential Medium with Earle's salts (EMEM, Gibco/BRL) with HEPES $26 \mathrm{mM}$, containing $2 \times$ concentration of vitamins, essential and non essential amino acids, and $20 \%$ serum (Gibco/BRL New Zealand). OF2 cells were grown in EMEM, with HEPES $26 \mathrm{mM}$ containing $2 \times$ concentration of vitamins, essential and non-essential amino acids and $15 \%$ serum. OF1 and OF2 cells were purchased from the Coriel Institute for Medical Research, Cadmen, NJ. YF1 cells (from ATCC) were cultured in EMEM, plus 2 mM L-glutamine, $1 \mathrm{mM}$ sodium pyruvate, $0.1 \mathrm{mM}$ non-essential amino acids and 10\% foetal bovine serum. YF2 cells (from ATCC) were grown in DMEM containing $10 \%$ foetal bovine serum plus $2 \mathrm{mM}$ glutamine. Total RNA was extracted from the cells using a commercially available kit (RNeasy, Qiagen). $1 \mu \mathrm{g}$ of total RNA was subjected to reverse transcription (M-MLV Reverse Transcriptase, GIBCO/BRL) to synthesize first strand CDNA. The Real Time Quantitative PCR (RTQ-PCR) has been performed as described. ${ }^{26}$ In each sample, the level of each transcript was normalized to the amount of c-Abl encoding mRNA whose levels are highly stable in human cells and in various cell lines (personal observation), and which was used as endogenous control for relative quantitation. The efficiency of RTQ-PCR for each of the mRNAs of interest and for C-Abl was assessed experimentally using the dilution method (see ref. ${ }^{26}$ ), prior to sample analysis. Relative quantitation can be represented by the following equation: $T_{0} / C_{0}=K \cdot(1+E)^{C t, E C}-C t, T$, where $T_{0}$ is the initial copy number of target mRNA; $C_{0}$ is the initial copy number of c-Abl mRNA; $E$ is the efficiency of amplification; $\mathrm{Ct}, \mathrm{EC}$ is the threshold cycle for $\mathrm{C}-\mathrm{Abl}$; and $\mathrm{Ct}, \mathrm{T}$ is the threshold cycle for target mRNA. ${ }^{26}$ The fold variation of each target mRNA in various samples was derived by the ratios of the relative quantitation performed in the sample and in the control RNA, i.e. (1+E) ( $\triangle \mathrm{Ct}, \mathrm{S}-\Delta \mathrm{Ct}, \mathrm{C})$, where $\Delta \mathrm{Ct}, \mathrm{S}$ is the difference $\mathrm{Ct}, \mathrm{EC}-\mathrm{Ct}, \mathrm{T}$ obtained in the sample, and $\triangle \mathrm{Ct}, \mathrm{C}$, is the same measure obtained in the control RNA used in the experiment. The primers and probes used are indicated in the table. For the quantitation of $\mathrm{C}-\mathrm{Abl}$ mRNA (Accession number: X16416) the primers and the probe used are: F.P.: TGGAGATAACACTCTAAGCATAACTAAAGGT; R.P.: GATGTAGTTGCTTGGGACCCA; Probe: CCATTTTTGGTTTGGGCTTCACACCATT. F.P., forward primer; R.P., reverse primer

Another experimental system that has been used to induce replicative senescence in vitro is based on the exposure of fibroblasts to low doses of oxidants. ${ }^{23-25} \mathrm{EF}_{28}$ cells, grown in the continuous presence of $100 \mu \mathrm{M}$ diethylmaleate (DEM), a glutathione depleting agent, stop growing after about 6 days, as demonstrated by their BrdU incorporation (about 5\%). Accordingly, p21 mRNA levels significantly increased and many cells became $\mathrm{SA} \beta$-gal positive ( $>45 \%$ ) (data not shown). In $\mathrm{EF}_{28}$ cells, after 6 days of mild oxidative stress, PTGS1 and Fmod mRNA levels are both decreased about six- and four-fold, respectively, compared to untreated cells and this modifica- tion is again opposite to that observed in OF cells compared to both YF populations. Therefore, the behaviour of PTGS1 and Fmod mRNAs demonstrate that the molecular phenotypes of in vitro induced senescence and in vivo acquired aging are distinguishable.

Two other genes analyzed are cathepsin C (CatC) and metalloproteinase (HME). As shown in Table 1, the first is expressed at similar levels in both $\mathrm{EF}_{28}$ and $\mathrm{EF}_{60}$ cells and in $\mathrm{EF}_{28}$ cells exposed to low concentrations of $\mathrm{DEM}$, and no significant difference is seen comparing both OF1 and OF2 cells with the counterparts taken from young donors or with the no longer dividing $\mathrm{OF}_{25}$ cells. HME mRNA was 
always increased, both in OF cells compared to $\mathrm{YF}$, in $\mathrm{EF}_{28}$ vs $\mathrm{EF}_{60}$ and in $\mathrm{EF}_{28}$ cells following mild oxidative stress. Therefore, HME mRNA modifications appear to be similar to those observed for p21 ${ }^{\text {waf1: }}$ they cannot distinguish between in vitro acquired senescence and in vivo cellular aging.

Five other genes showed a behaviour completely different from those described above. Table 1 shows that the mRNAs encoding cyclin A (CycA), cyclin F (CycF), thymidylate synthase (TS), hepatocyte nuclear factor-3/fork head homolog $11 \mathrm{~A}(\mathrm{HFH}-11 \mathrm{~A})$ and cyclin-sensitive ubiquitin carrier protein (Ucar) are many fold decreased in $\mathrm{EF}_{60}$ cells compared to $\mathrm{EF}_{28}$. Similarly, $\mathrm{EF}_{28}$ cells exposed to low doses of DEM displayed a significant decrease of these mRNAs after 2 days of treatment, except for TS mRNA whose level decreases starting from day 4 . It is worth noting that the extent of the decreases observed in the cells treated for 6 days with DEM are, in many cases, several fold higher that those observed in $\mathrm{EF}_{60}$ cells.

Surprisingly, OF1 and OF2 cells compared to YF1 and YF2 cells did not show any significant change in the expression of these mRNAs (Table 1, columns 1,2). On the contrary, OF1 cells, grown until they have reached 25 PDL $\left(\mathrm{OF}_{25}\right)$ and no longer incorporating BrdU, show a significant decrease of the mRNA levels of all the five genes (Table 1, column 3). Therefore, the levels of these five genes appear to be modified only in cells which have ceased to grow, regardless their origin.

In summary, these experiments demonstrate that it is possible to distinguish the molecular phenotype of human fibroblasts which have acquired the senescent phenotype in vitro, either by repeated in vitro passages or by mild oxidant treatment, with that of fibroblasts taken from old individuals (i.e. in vivo acquired senescence). Two examples of the differences between in vitro and in vivo acquired senescence are the genes encoding prostaglandin endoperoxidase synthase and fibromodulin. Their opposite behaviours in the two senescent phenotypes support the hypothesis that other genes could also be regulated in a similar fashion.

The existence of a gene expression profile characteristic of in vitro senescent cells, regardless of their origin, is suggested by the changes observed in the expression of some other genes, including cyclin $A$, cyclin $F$, thymidylate synthase, hepatocyte nuclear factor-3/fork head homolog $11 \mathrm{~A}$ and cyclin-sensitive ubiquitin carrier protein. All these genes encode proteins that play a role in cell cycle progression, and it is reasonable that in a cell, no longer dividing but still surviving, many of the genes involved in S-, G2- and M-phases of the cell cycle are downregulated.

\section{Acknowledgements}

This work has been supported by grants from the Italian National Research Council (CNR), Special Project 'Biotecnologie', PSt/74 'Biologia dell' invecchiamento e sue conseguenze sul sistema assistenziale', programma CNR-Agenzia 2000 and from Ministero dell'Università e della Ricerca Scientifica e Tecnologica (COFIN 2000 and Piano 'Biomedicina', Prog. N.1).

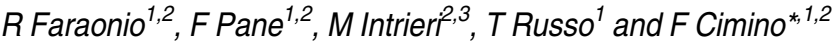 \\ 1 Dipartimento di Biochimica e Biotecnologie Mediche, Università di Napoli Federico II, Napoli, Italy \\ 2 CEINGE S.c.a.r.I. Biotecnologie Avanzate, Napoli, Italy \\ ${ }^{3}$ Dipartimento S.T.A.T., Facoltà Scienze Matematiche, Fisiche e Naturali, Università del Molise, Isernia, Italy \\ * Corresponding author: Filiberto Cimino, Dipartimento di Biochimica e Biotecnologie Mediche, Università di Napoli Federico II, via S. Pansini 5, 80131 Napoli, Italy; E-mail: cimino@dbbm.unina.it}

1. Hayflick L et al. (1961) Exp. Cell Res. 25: 585-621.

2. Pereira-Smith OM et al. (1988) Proc. Natl. Acad. Sci. 85: 6042-6046.

3. Noda A et al. (1994) Exp.Cell Res. 211: 90-98.

4. Stein GH et al. (1990) Science 249: 666-669.

5. Dimri GP et al. (1996) Mol. Cell Biol. 16: 2987-2997.

6. Harley CB et al. (1990) Nature 345: 458-460.

7. Bis Bodnar AG et al. (1998) Science 279: 349-352.

8. Hayflik L (1965) Exp. Cell Res. 37: 614-636.

9. Schneider EL et al. (1996) Proc. Natl. Acad. Sci. 73: 3584-3588

10. Bruce SA et al. (1986) Mech. Ageing Dev. 34: 151-173.

11. Smith JR et al. (1978) Proc. Natl. Acad. Sci. 75: 1353-1356.

12. Allsopp RC et al. (1992) Proc. Natl. Acad. Sci. USA 89: 10114-10118.

13. Martin GM et al (1970) Lab. Invest. 23: 86-92.

14. Oshima J et al. (1995) J. Cell Physiol. 162: 277-283.

15. Goldstein S et al (1979) Fed. Proc. 38: 1862-1867.

16. Danes BS (1971) J. Clin. Invest. 50: 2000-2003.

17. Schneider EL et al. (1972) Proc. Soc. Exp. Biol. Med. 141: 1092-1094.

18. Cristofalo VJ et al (1998) Proc. Natl. Acad. Sci. 95: 10614-10619.

19. Dimri GP et al. (1995) Proc. Natl. Acad. Sci. 92: 9363-9367.

20. Ogryzko VV et al (1996) Mol. Cell Biol. 16: 5210-5218.

21. Alcorta DA et al. (1996) Proc. Natl. Acad. Sci. 93: 13742-13747.

22. Ly DH et al. (2000) Science 287: 2486-2492.

23. Chen $Q$ et al. (1994) Proc. Natl. Acad. Sci. 91: 4130-4134.

24. Chen QM et al (1998) Biochem. J. 332: 43-50.

25. Chen QM et al. (2001) Exp. Cell Res. 265: 294-303.

26. Fink L et al. (1998) Nat. Med. 4: 1329-1333. 